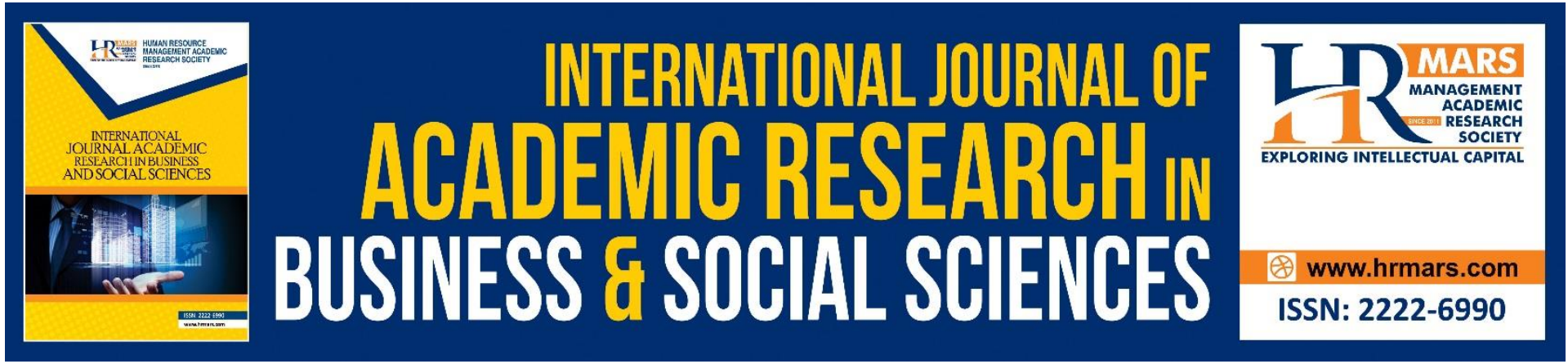

\title{
A Study on Perception of Students' Readiness towards Online Learning During Covid-19 Pandemic
}

\author{
Fathiyah Mohd Kamaruzaman, Nur Ainil Sulaiman, Nor Azwahanum Nor \\ Shaid
}

To Link this Article: http://dx.doi.org/10.6007/IJARBSS/v11-i7/10488

DOI:10.6007/IJARBSS/v11-i7/10488

Received: 22 May 2021, Revised: 27 June 2021, Accepted: 11 July 2021

Published Online: 30 July 2021

In-Text Citation: (Kamaruzaman et al., 2021)

To Cite this Article: Kamaruzaman, F. M., Sulaiman, N. A., \& Shaid, N. A. N. (2021). A Study on Perception of Students' Readiness towards Online Learning During Covid-19 Pandemic. International Journal of Academic Research in Business and Social Sciences, 11(7), 1536-1548.

Copyright: (c) 2021 The Author(s)

Published by Human Resource Management Academic Research Society (www.hrmars.com)

This article is published under the Creative Commons Attribution (CC BY 4.0) license. Anyone may reproduce, distribute, translate and create derivative works of this article (for both commercial and non-commercial purposes), subject to full attribution to the original publication and authors. The full terms of this license may be seen

at: http://creativecommons.org/licences/by/4.0/legalcode

Vol. 11, No. 7, 2021, Pg. 1536 - 1548

http://hrmars.com/index.php/pages/detail/IJARBSS

JOURNAL HOMEPAGE

Full Terms \& Conditions of access and use can be found at http://hrmars.com/index.php/pages/detail/publication-ethics 


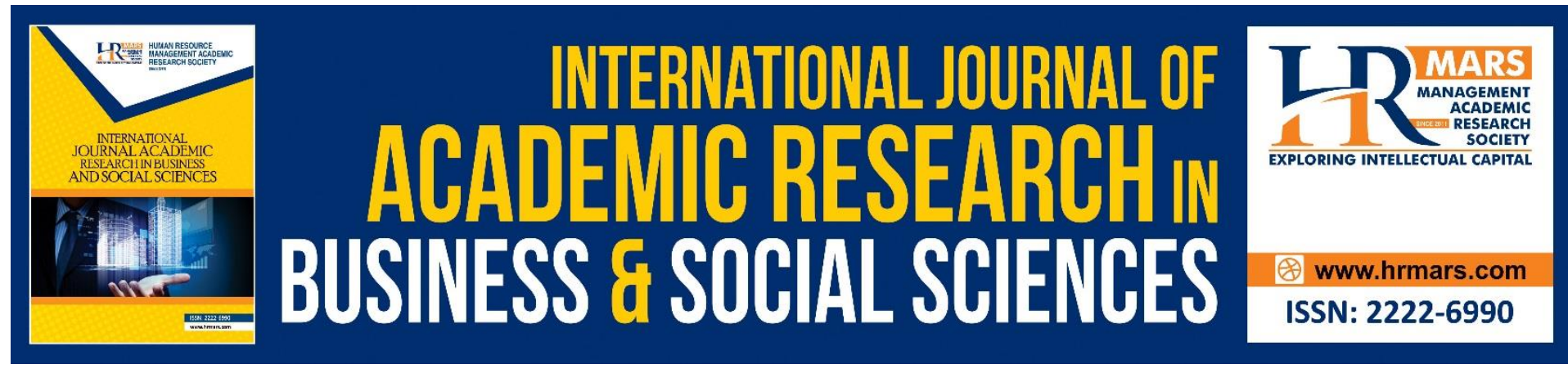

\title{
A Study on Perception of Students' Readiness towards Online Learning During covid-19 Pandemic
}

\author{
Fathiyah Mohd Kamaruzaman, Nur Ainil Sulaiman, Nor \\ Azwahanum Nor Shaid \\ Faculty of Education, Universiti Kebangsaan Malaysia, 43600 Bangi \\ Email address: fathiyah@ukm.edu.my
}

\begin{abstract}
Pandemic COVID-19 has given a significant impact and change the normal way of live whereby online learning has become the main way to teach and learn. In line with the emerging use of online learning, it is crucial to identify whether the students are ready and fit enough for online class or not. By knowing the level of readiness towards online learning, the educators can make full use of online learning in order to help the students to gain knowledge, apply the knowledge, upgrade their skills and performed well in their study. This study examines the students' perception on readiness towards the use of online learning at the university level during the COVID-19 pandemic. Student readiness of online learning can be assessed comprehensively from five main domains which consists of motivation, possession of facilities or equipment for online learning, capability to assess and use technology, usefulness of online learning and self-directed learning. For this study, the quantitative approach has been adopted and responses from 65 undergraduate students of Faculty of Education, Universiti Kebangsaan Malaysia were collected through online questionnaire. This research study was conducted during April - June 2021. Data collected were analysed using Statistical Package Social Science 23 (SPSS 23) software and presented in the form of percentages and mean scores. Main findings obtained from this study revealed that undergraduate students were ready towards the use of online learning in term of their motivation $(M=3.77)$, facilities $(M=$ 3.93) and technology capabilities $(M=3.92)$. Based on this finding, the study recommend that constant reminder and structured assignment should be given to the students in order to help them to be ready for self-directed learning and they able to improve relevant skills during online learning. Further study should be done to identify the relationship between students' readiness with their academic achievement in order to see the effectiveness of online learning during COVID-19 pandemic
\end{abstract}

Keywords: Readiness, Online Learning, COVID-19

\section{Introduction}

Education is a need in this world today, so does the technology. Recently, pandemic COVID19 has given a significant impact and change the normal way of live including communication, health and education. Daniel (2020) mentioned that COVID-19 has change the education 
system related to curriculum, educator functions, student positions and assessments. In another report, COVID-19 has also changed the way of educating future generations and led to redefining the role of educators (Luthra, \& Mackenzie, 2020). Suddenly the online learning has become widely known among educators and they are forced to use it due to the closure of schools by most governments around the world. In line with this, many efforts have been put by the universities to develop the online learning system. According to Abdul (2018), online learning is one of important aspect for future education or Education 4.0 in order to produce highly creative graduates. This will become the challenges for both educators and students to adapt and dealing with online learning.

In line with the emerging use of online learning, it is crucial to identify whether the students are ready and fit enough for online class or not. By knowing the level of readiness towards online learning, the educators can make full use of online learning in order to help the students to gain knowledge, apply the knowledge, upgrade their skills and performed well in their study. Additionally, it is believed that online learning is the ideal solution that can be opted for teaching and learning as it is more safe and sustainable during COVID-19 pandemic. Therefore, objective of the study is to identify the level of readiness toward online learning among undergraduate students in Malaysia. Five research questions are addressed in this study as follows :

1) What are the level of students' readiness from aspect of motivation?

2) What are the level of students' readiness from aspect facilities or equipment?

3) What are the level of students' readiness from aspect technology capabilities?

4) What are the level of students' readiness from aspect usefulness of online learning?

5) What are the level of students' readiness from aspect self-directed learning?

\section{Literature Review}

\section{Online learning readiness during COVID-19}

The concept of readiness for online learning was proposed in the Australian vocational education and training sector by Warner, Christie and Choy (1998). The term of online learning have been used interchangeably to e-learning, web-based learning, mixed learning and virtual learning (Smart \& Cappel, 2006; Aminuddin et al., 2021). Kharve and Gogia (2016) defined online learning or e-learning is a process of learning by electronic means which involves the use of computer, mobile phone or other electronic devices and accessing internet.

Readiness can be operationalized as preparedness of student to respond to changes and adapt to online learning as a new way of delivering lectures/classes (Smart \& Cappel, 2006). Thus it is significant to study the students' readiness towards online learning as it entails students' competence, confidence in using technological tools and the ability to participate in self-directed learning. Nganga, Waruru and Nakweya (2020) mentioned that online learning preparedness varies from one institution to the other, whereby not all the student and lecturers had been trained to participate in online learning and most students do not have device or allocation to buy internet bundles.

A study by Paechter and Maier (2010) found that Austrian students are still preferred face-toface learning to interact and learn effectively. In another study, Orton-Johnson (2009) 
recorded a similar result from the students in the UK where the students were more favoured to use physical text materials rather than online materials during learning. In contrast, local study by Adams, Sumintono, Mohamed and Noor (2018) found that the level of readiness of online learning in higher education institutes as learning tools are at a satisfactory level.

Recent study by Olayemi, Adamu and Olayemi (2021) investigated the readiness of one hundred and forty-eight undergraduate students' towards online learning in Nigeria revealed that majority of the respondents claimed to be conversant with online learning with a high level of readiness. Also, majority of the respondents indicated high level of ICTs skills and competencies needed for online learning. On the negative side, fear of high cost of data, poor internet services, erratic power supply, inaccessibility to online library resources and limited access to computer were the major perceived challenges to effective online learning.

The study conducted by Widodo, Wibowo and Wagiran (2020) has identified five domains regarding the readiness of online learning which are : (i) students' motivation, (ii) possession of facilities or equipment for online learning, (iii) students' ability to assess and use technology, (iv) usefulness of online learning and (v) self-directed learning during online learning.

\section{Methodology}

The study employed a descriptive survey research design. The target population of this study were all undergraduate students from Faculty of Education, Universiti Kebangsaan Malaysia. A total of 65 undergraduate student participated in this study by filling the questionnaire given. A structured questionnaire was used as the instrument for data collection. The questionnaire was adopted from previous studies by Hung et al. (2009), Akaslan \& Law (2011), Cole, Shelly \& Swartz (2014), Doculan (2016), Khan et al. (2020), Sharma et al. (2020), Abdillah \& Musa (2021), Olayemi, Adamu \& Olayemi (2021). The questionnaire consist of two parts (Part A and Part B). Part A comprises of background information of participants regarding gender, race, academic year, course of study and internet accessibility. Meanwhile, Part B consists of five domains of readiness towards online learning. Five likert scale was employed for each item ranging from 1 = Strongly Disagree (SD), $2=$ Disagree (D), $3=$ Neutral (N), $4=$ Agree (A), 5 = Strongly Agree (SA). Table 1 shows the item for each dimensions and its references. 
Table 1. Five domains of readiness towards online learning

\begin{tabular}{|c|c|c|}
\hline Bil & Item & References \\
\hline \multicolumn{3}{|c|}{ Motivation for students in participating in online learning } \\
\hline \multirow[t]{2}{*}{1} & I am open to learn about new things regarding & Hung et al. (2009) \\
\hline & online learning. & Abdillah \& Musa (2021) \\
\hline 2 & I have broad interest in ICT. & Abdillah \& Musa (2021) \\
\hline 3 & $\begin{array}{l}\text { I am positive about the use of technology in online } \\
\text { learning. }\end{array}$ & Abdillah \& Musa (2021) \\
\hline \multirow[t]{3}{*}{4} & I am able to spend significant time and energy to & Akaslan \& Law (2011) \\
\hline & engage in online learning class. & Doculan (2016) \\
\hline & & Abdillah \& Musa (2021) \\
\hline \multirow[t]{4}{*}{5} & I am confident to use online learning system. & Akaslan \& Law (2011) \\
\hline & & Cole, Shelly \& Swartz (2014) \\
\hline & & Khan et al. (2020) \\
\hline & & Sharma et al. (2020), \\
\hline \multirow[t]{2}{*}{6} & I am updated with the latest technology & Cole, Shelly \& Swartz (2014) \\
\hline & & Sharma et al. (2020) \\
\hline \multicolumn{3}{|c|}{ Facilities or equipment for online learning } \\
\hline \multirow[t]{4}{*}{7} & I own a device to access online learning & Akaslan \& Law (2011) \\
\hline & & Doculan (2016) \\
\hline & & Abdillah \& Musa (2021) \\
\hline & & $\begin{array}{l}\text { Olayemi, Adamu \& Olayemi } \\
\text { (2021) }\end{array}$ \\
\hline \multirow[t]{3}{*}{8} & I have access to necessary software installed. & Akaslan \& Law (2011) \\
\hline & & Doculan (2016) \\
\hline & & Abdillah \& Musa (2021) \\
\hline 9 & I have access to a printer installed. & Doculan (2016) \\
\hline \multirow[t]{4}{*}{10} & I have access to a stable internet connection at & Akaslan \& Law (2011) \\
\hline & home. & Doculan (2016) \\
\hline & & Abdillah \& Musa (2021) \\
\hline & & $\begin{array}{l}\text { Olayemi, Adamu \& Olayemi } \\
\text { (2021) }\end{array}$ \\
\hline \multirow[t]{2}{*}{11} & I have access to a computer installed with search & Doculan (2016) \\
\hline & $\begin{array}{l}\text { engines (eg. Google, Ask) and internet browsers } \\
\text { (eg. IE, Firefox, Google Chrome). }\end{array}$ & Akaslan \& Law (2011) \\
\hline 12 & I have a virus protection on my computer. & Doculan (2016) \\
\hline 13 & $\begin{array}{l}\text { I feel internet connection strength determines our } \\
\text { effective learning opportunity. }\end{array}$ & $\begin{array}{l}\text { Olayemi, Adamu \& Olayemi } \\
\text { (2021) }\end{array}$ \\
\hline \multicolumn{3}{|c|}{ Ability of students to access and use technology } \\
\hline 14 & I am familiar with online etiquette. & Doculan (2016) \\
\hline 15 & $\begin{array}{l}\text { I know the basic functions of computer hardware } \\
\text { components (CPU and monitor) including its } \\
\text { peripherals like the printer, speaker and mouse. }\end{array}$ & Doculan (2016) \\
\hline 16 & $\begin{array}{l}\text { I know how to use online learning application (eg } \\
\text { : Google Classroom, Google Meet, Zoom). }\end{array}$ & Abdillah \& Musa (2021) \\
\hline 17 & $\begin{array}{l}\text { I know how to use web browsers (eg. Internet } \\
\text { Explorer, Google Chrome). }\end{array}$ & Doculan (2016) \\
\hline
\end{tabular}




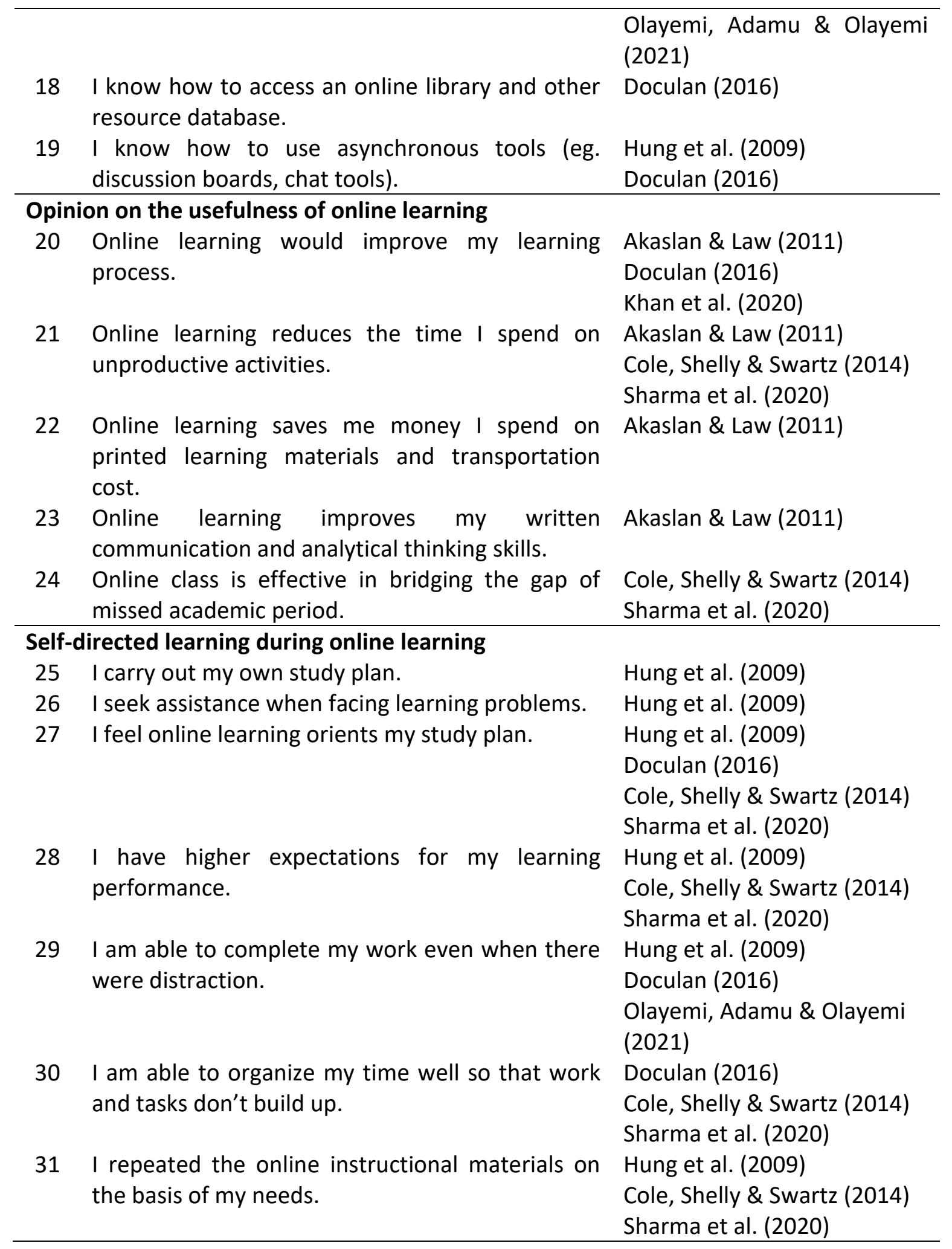

To ensure validity of the questionnaire, face and content validity was done by two experts in the field of education that were involve in online teaching and learning during the COVID-19 pandemic. The researcher gathered the number of agreed and disagreed items to be calculated using the Cohen Kappa Agreement Level Indicator refer from Bernard and Ryan (2010). The $\mathrm{K}_{\mathrm{f}}$ value obtained is 0.80 , which indicate substantial agreement between the experts. 
In term of reliability of the instrument, the Cronbach's alpha was determined to verify the reliability of the instrument. Based from pilot study that has been conducted to 35 undergraduates students from other faculties in Universiti Kebangsaan Malaysia, the value of Cronbach Alpha obtained for domain motivation is 0.867 , domain facilities or equipment is 0.935 , domain ability is 0.922 , domain usefulness is 0.888 and self-directed learning is 0.973 . The Cronbach Alpha coefficient for overall items is 0.973 is considered strong reliability level. This means that the instrument is reliable. Table 2 shows the Cronbach Alpha value for overall and each domain.

Table 2. Cronbach Alpha Coefficient

\begin{tabular}{lcc}
\hline \multicolumn{1}{c}{ Domains } & Number of Items & Cronbach Alpha \\
\hline Motivation & 6 & 0.867 \\
Facilities or & 7 & 0.935 \\
equipment & & \\
Ability & 6 & 0.922 \\
Usefulness & 5 & 0.888 \\
Self-directed learning & 7 & 0.973 \\
Overall & $\mathbf{3 1}$ & $\mathbf{0 . 9 7 3}$ \\
\hline
\end{tabular}

The questionnaire was administered to the respondents through online via Google form. The link was given to the students' representative of each course of study to be shared across all undergraduate students in Faculty of Education. Data was collected between the periods of April-June 2021. The data obtained was extracted, cleaned and transferred onto Statistical Package for Social Sciences (SPSS) version 23 for the analysis. Findings were presented using means in form of table. In interpreting the readiness of students towards online learning during COVID-19 pandemic, the researcher refers to interpretation of readiness from Aydin and Tassi (2005) as shown in Figure 1. As the choices were coded as 1, 2, 3, 4 or 5, it is suggested that the mean score of 3.40 can be identified as the expected level of readiness for online learning. It is because a five-point scale contains 4 intervals and 5 categories with the ratio 4 / 5 being equal to 0.8 . Interpretation of mean score as display in Table 3 as cited from Pallant (2010).

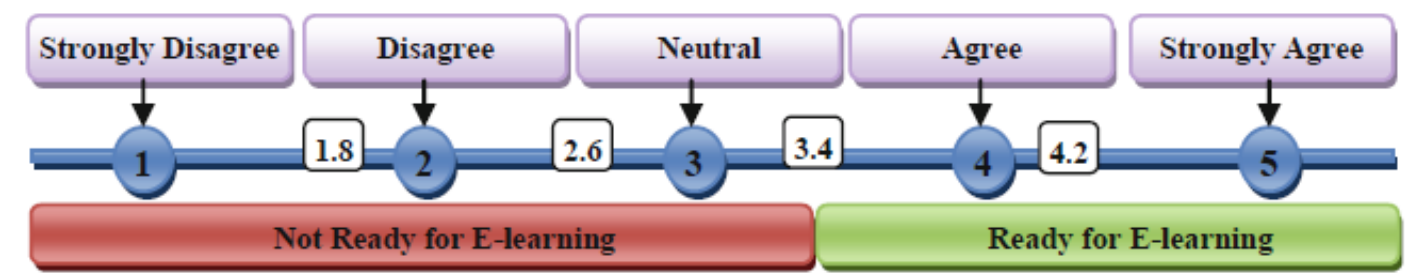

Figure 1. Interpretation to measure readiness towards online learning

Table 3. Mean score interpretation

\begin{tabular}{cc}
\hline Mean score & Interpretation \\
\hline $1.00-2.33$ & Low \\
$2.24-3.67$ & Intermediate \\
$3.68-5.00$ & High \\
\hline
\end{tabular}




\section{Results \& Discussion}

\section{Demography Characteristic}

The demographic information obtained in this study are in terms of gender, race, academic year, course of study and internet accessibility as shown in Table 4.

By referring to the gender data, $67.7 \%$ of the respondents are female and $23.2 \%$ of them are male respondents. Most of respondents are Malay students with $89.2 \%$, Chinese students with $1.5 \%$, Indian students with $4.6 \%$ and Others with $4.5 \%$. Furthermore, majority of the respondents is in academic Year 1 (63.2\%), Year 2 (23.1\%), Year $3(12.3 \%)$ and Year 4 (1.5\%). The largest group of respondents participated in this study are from Special Education course with $56.9 \%$, followed by Teaching English as a Second Language course with $27 . \%$ and Sports \& Recreation course with $15.4 \%$. Lastly, $80.0 \%$ of the respondents mentioned that they have internet accessibility meanwhile $20.0 \%$ of the respondents did not have access to internet.

Table 4. Demography analysis of the respondents

\begin{tabular}{|c|c|c|}
\hline \multicolumn{3}{|l|}{ Demography characteristic } \\
\hline Gender & Frequency & Percentage (\%) \\
\hline Male & 21 & 32.3 \\
\hline \multirow[t]{2}{*}{ Female } & 44 & 67.7 \\
\hline & 65 & 100 \\
\hline Race & Frequency & Percentage \\
\hline Malay & 58 & 89.2 \\
\hline Chinese & 1 & 1.5 \\
\hline Indian & 3 & 4.6 \\
\hline \multirow[t]{2}{*}{ Others } & 3 & 4.5 \\
\hline & 65 & 100 \\
\hline Academic year & Frequency & Percentage \\
\hline Year 1 & 41 & 63.1 \\
\hline Year 2 & 15 & 23.1 \\
\hline Year 3 & 8 & 12.3 \\
\hline \multirow[t]{2}{*}{ Year 4} & 1 & 1.5 \\
\hline & 65 & 100 \\
\hline Course of study & Frequency & Percentage \\
\hline Special Education & 37 & 56.9 \\
\hline Teaching English as a Second Language & 18 & 27.7 \\
\hline Sports \& Recreation & 10 & 15.4 \\
\hline \multirow[b]{2}{*}{ Internet accessibility } & 65 & 100 \\
\hline & Frequency & Percentage \\
\hline Yes & 52 & 80.0 \\
\hline \multirow[b]{2}{*}{ Total } & 13 & 20.0 \\
\hline & 65 & 100 \\
\hline
\end{tabular}

\section{Students' readiness towards online learning}

In identifying the perception of students' readiness towards online learning during COVID-19 pandemic, five domains of students' readiness were investigated as proposed by previous 
studies. The mean value for each domain is calculated and discussed. Table 5 displays the data for first domain, which is motivation for students to participate in an online learning.

Table 5. Mean value for domain motivation

\begin{tabular}{|c|c|c|}
\hline \multicolumn{3}{|c|}{ Domain : Motivation for students in participating in online learning } \\
\hline Statements & Mean (M) & Interpretation \\
\hline $\begin{array}{l}\text { I am open to learn about new things regarding online } \\
\text { learning }\end{array}$ & 4.09 & High \\
\hline I have broad interest in ICT & 3.71 & High \\
\hline $\begin{array}{l}\text { I am positive about the use of technology in online } \\
\text { learning }\end{array}$ & 3.92 & High \\
\hline $\begin{array}{l}\text { I am able to spend significant time and energy to } \\
\text { engage in online learning class }\end{array}$ & 3.62 & Intermediate \\
\hline I am confident to use online learning system & 3.40 & Intermediate \\
\hline I am updated with the latest technology & 3.89 & High \\
\hline Total & 3.77 & High \\
\hline
\end{tabular}

Referring to Table 5, four items show high mean score. The respondents agreed that they are open to learn about new things regarding online learning $(M=4.09)$, they have broad interest in ICT $(M=3.71)$, they are positive about the use of technology in online learning $(M=3.92)$ and they are updated with the latest technology $(M=3.89)$. Meanwhile, there were 2 items that show intermediate mean score which are ability to spend significant time and energy to engage in online learning class $(M=3.62)$ and confident to use online learning system $(M=$ 3.40). Overall mean scores obtained is $M=3.77$ which indicated high mean score that reflect a good level of readiness. It can be concluded that undergraduates' students were ready and motivated to engage in online learning. This finding is consistent with the finding from Saadé et al. (2007) which stated that motivation may play an important role in online learning. This result is in contrast with the findings of Qunfei, Abdullah and Mustapha (2020) which found that online learning weakened students' motivation, in turn resulted low level of acceptance and poor learning outcomes.

Table 6. Mean value for domain facilities or equipment

\begin{tabular}{lcc}
\hline \multicolumn{3}{c}{ Domain : Facilities or equipment for online learning } \\
Statements & Mean (M) & Interpretation \\
\hline I own a device to access online learning & 4.12 & High \\
I have access to necessary software installed & 3.89 & High \\
I have access to a printer installed & 3.66 & Intermediate \\
I have access to a stable internet connection at home & 3.62 & Intermediate \\
I have access to a computer installed with search & 4.20 & High \\
engines (eg. Google, Ask) and internet browsers (eg. IE, & & \\
$\begin{array}{l}\text { Firefox, Google Chrome) } \\
\text { I have a virus protection on my computer }\end{array}$ & 3.77 & High \\
I feel internet connection strength determines our & 4.22 & High \\
effective learning opportunity & & High \\
\hline
\end{tabular}


Five items under domain facilities or equipment shows high level of mean score. The items are I own a device to access online learning $(M=4.12)$, I have access to necessary software installed ( $M=3.89)$, I have access to a computer installed with search engines (eg. Google, Ask) and internet browsers (eg. IE, Firefox, Google Chrome) $(M=4.20)$, I have a virus protection on my computer ( $M=3.77)$ and I feel internet connection strength determines our effective learning opportunity ( $M=4.22)$. Meanwhile, two items with intermediate level of mean score are I have access to a printer installed $(M=3.66)$ and I have access to a stable internet connection at home $(M=3.62)$. Overall mean scores revealed high level of mean score $(M=3.93)$. The high mean score indicates that the respondents were ready towards online learning in regard the facilities or equipment for online learning. They have necessary equipment for online teaching such as the suitable device, software and internet connection. However, the respondents feel like they did not have stable internet connection to assist them during online learning. This finding is in agreement with study by Anwar et al. (2020) which also found that $65.8 \%$ of the respondents were having unstable Internet connection that lead to several problems while undergoing virtual classes, for instance, a glitch during online group presentations, taking a long time to submit assignments or connection error while they are sitting for online tests or exams.

Table 7. Mean value for domain ability to use and assess technology

\section{Domain : Ability to use and assess technology}

\begin{tabular}{lcc} 
Statements & Mean (M) & Interpretation \\
\hline I am familiar with online etiquette. & 3.69 & $\begin{array}{c}\text { High } \\
\text { High }\end{array}$ \\
I know the basic functions of computer hardware & 3.78 & \\
$\begin{array}{l}\text { components (CPU and monitor) including its } \\
\text { peripherals like the printer, speaker and mouse }\end{array}$ & & High \\
I know how to use online learning application (eg : & 4.25 & High \\
$\begin{array}{l}\text { Google Classroom, Google Meet, Zoom) } \\
\text { I know how to use web browsers (eg. Internet }\end{array}$ & 4.26 & High \\
$\begin{array}{l}\text { Explorer, Google Chrome) } \\
\text { I know how to access an online library and other } \\
\text { resource database }\end{array}$ & 3.77 & High \\
I know how to use asynchronous tools (eg. discussion \\
boards, chat tools)
\end{tabular}

Mean scores for all items under domain ability to use and assess technology show a high level mean score. This finding indicates that respondents were capable to use and know how to assess the technology very well. Respondents agreed that they are familiar with online etiquette with $M=3.69$, they know the basic functions of computer hardware components and its peripherals with $M=3.78$, they know how to use online learning application like Google Classroom, Google Meet, Zoom with $M=4.25$, they know how to use web browsers with $M=4.26$, they know how to access an online library and other resource database with $M=3.77$ and they know how to use asynchronous tools such as discussion board and chart tools $(M=3.74)$. Based from the result, having the right attitude, knowledge and basic information about the technology use during online learning may help the students to be ready to engage in online learning. This is in line with the study by Olayemi, Adamu and 
Olayemi (2021) which assert that the level of students' proficiency (skills and competencies) in the use and handling the technology is vital to the success of online learning.

Table 8. Mean value for domain usefulness of online learning

\begin{tabular}{|c|c|c|}
\hline \multicolumn{3}{|c|}{ Domain : Usefulness of online learning } \\
\hline Statements & Mean (M) & Interpretation \\
\hline Online learning would improve my learning process & 3.58 & Intermediate \\
\hline $\begin{array}{l}\text { Online learning reduces the time I spend on } \\
\text { unproductive activities }\end{array}$ & 3.43 & Intermediate \\
\hline $\begin{array}{l}\text { Online learning saves me money I spend on printed } \\
\text { learning materials and transportation cost }\end{array}$ & 3.74 & High \\
\hline $\begin{array}{l}\text { Online learning improves my written communication } \\
\text { and analytical thinking skills }\end{array}$ & 3.34 & Intermediate \\
\hline $\begin{array}{l}\text { Online class is effective in bridging the gap of missed } \\
\text { academic period }\end{array}$ & 3.49 & Intermediate \\
\hline Total & 3.52 & Intermediate \\
\hline
\end{tabular}

As shown in Table 8, only one item shows high level of mean score. The respondents stated that online learning saves the money they spend on printed learning materials and transportation cost. Meanwhile other items under domain usefulness of online learning were in intermediate level of mean scores. Overall, mean score for this domain is 3.52 shows intermediate level of readiness. This finding indicates that online learning have intermediate usefulness to the students in term of their learning process, improvement of written communication and time management. However, previous study showed that online learning able to enhance students' learning (Akaslan \& Law 2011).

Table 9. Mean value for domain self-directed learning during online learning

\begin{tabular}{|c|c|c|}
\hline \multicolumn{3}{|c|}{ Domain : Self-directed learning during online learning } \\
\hline Statements & Mean (M) & Interpretation \\
\hline I carry out my own study plan & 3.68 & High \\
\hline I seek assistance when facing learning problems & 3.80 & High \\
\hline I feel online learning orients my study plan & 3.45 & Intermediate \\
\hline $\begin{array}{l}\text { I have higher expectations for my learning } \\
\text { performance }\end{array}$ & 3.63 & Intermediate \\
\hline $\begin{array}{l}\text { I am able to complete my work even when there were } \\
\text { distraction }\end{array}$ & 3.45 & Intermediate \\
\hline $\begin{array}{l}\text { I am able to organize my time well so that work and } \\
\text { tasks don't build up }\end{array}$ & 3.31 & Intermediate \\
\hline I repeated the online instructional materials on the & 3.71 & High \\
\hline Total & 3.58 & Intermediate \\
\hline
\end{tabular}

Table 9 illustrates the readiness level of students towards self-directed learning during online learning. Based on the analysis, three items show high level of mean score. The items are (i) I carry out my own study plan ( $M=3.68)$, (ii) I seek assistance when facing learning problems ( $M=3.80$ ) and (iii) I repeated the online instructional materials on the basis of my needs ( $M$ = 3.71). Meanwhile other four items show intermediate level of mean score. Overall, the students feel that they are moderately ready for self-directed learning during online learning. 
The students having trouble to organize their time, did not able to complete the work because of distraction, they have moderate expectation of learning performance and they need to plan their study independently. This finding is in agreement with the study by Khair Anwar et al (2020), who mentioned that the students still need more guidance and time to adapt with online learning.

\section{Conclusion}

Higher learning institutions have activated the online learning mode and postponed all outof-campus activities due to the rapid spread of COVID-19 worldwide. The shift from traditional face-to-face classes towards online learning classes is to ensure continuity of education for students as well as to ensure the safety of both educators and students. This study revealed that undergraduate students were ready towards the use of online learning in term of their motivation, facilities and technology capabilities. However, the students feel that they were moderately ready for the usefulness and self-directed learning during online learning. Based from these outcome, it is recommended that educators to use online learning because the students are ready especially they have enough facilities to help them towards online learning. Despite that, educators need to emphasize on assisting the students to complete their work by giving constant reminder and learning materials that can help them to elevate their skills.

\section{References}

Haseeb, A. (2018). Higher Education in the Era of IR 4.0. New Straits Times. Retrieved from https://www.nst.com.my/education/2018/01/323591/higher-education-era-ir-40.

Abdillah \& Musa. (2021). Student Readiness to teaching and learning new norm in the Department of Information \& Communication Technology Polytechnic Sultan Mizan Zainal Abidin. International Journal of Modern Education, 3(8), 114-124. doi :10.35631/IJMOE.380010 (In Malay)

Adams, D., Sumintono, B., Mohamed, A., \& Noor, N. S. M. (2018). E-Learning Readiness Among Students of Diverse Backgrounds in A Leading Malaysian Higher Education Institution. Malaysian Journal of Learning and Instruction, 15(2), 227-256.

Akaslan, D., \& Law, E. L.-C. (2011). Measuring Student e-learning Readiness: A Case About the Subject of Electricity in Higher Education Institutions in Turkey. In H. Leung, E. Popescu, Y. Cao, R. W. H. Lau, \& W. Nejdl (Eds.), Advances in Web-based Learning, Proceedings of ICWL 2011 (pp. 209-218) . LNCS 7048. Berlin, Heidelberg, \& New York: Springer.

Aminuddin, A. S., Azmi, M. N. F., Sulaiman, M. A., \& Saini, N. A. (2021). Readiness for online distance learning (ODL): Understanding the attitudes among students in UITM Pahang. e-Proceedings of International Conference on Language, Education, Humanities \&Social Sciences (i-LEdHS2021)

Aydin, C. H., \& Tasci, D. (2005). Measuring readiness for e-learning. Educational Technology and Society, 244-257.

Bernard, H. R., \& Ryan, G. W. (2010). Analysing Qualitative Data: Systematic Approaches. UK : SAGE Publication Inc.

Cole, M. T., Shelley, D. J., \& Swartz, L. B. (2014). Online instruction, e-learning, and student satisfaction: A three-year study. The International Review of Research in Open and Distributed Learning, 15(6). 
Daniel, S. J. (2020). Education and the COVID 19 Pandemic. Prospects, 49, 91-96. https://doi.org/10.1007/s11125-020-09464-3

Doculan, A. A. D. (2016). E-learning Readiness Assessment Tool for Philippine Higher Education Institutions. International Journal on Integrating Technology in Education, 5(2), 33-43.

Hung, M. L., Chou, C., Chen, C. H., \& Own, Z. Y. (2010). Learner readiness for online learning: Scale development and student perceptions. Computers \& Education, 55, 1080-1090.

Anwar, K. I. S., Omar, N., Isa, M. N. S., \& Shamsudin, S. M. (2020). Students' Acceptance and Readiness towards Distrance Learning during COVID-19 Pandemic. International Journal of Education and Pedagogy, 2(4), 39-50.

Khan, M. A., Vivek, Nabi, M. K., Khojah, M., \& Tahir, M. (2021). Students' Perception towards E-Learning during COVID-19 Pandemic in India: An Empirical Study. Sustainability, 13(57). https://dx.doi.org/10.3390/su13010057

Kharve, D., \& Gogia, A. (2016). E-learning: Student's perception in developing countries like India. Advances in Computer Science and Information Technology, 3(5), 389-395.

Luthra, P., \& Mackenzie, S. (2020). 4 Ways Covid-19 Education Future Generations. https://www.weforum.org/agenda/2020/03/4-ways-covid-19-educationfuturegenerations/

Nganga, G., Waruru, M., \& Nakweya, G. (2020). Universities face multiple challenges in wake of COVID-19 closures. University world news. https://www.universityworldnews.com/post.php?story=20200407162549396

Olayemi, M. S., Adamu, H., \& Olayemi, K. J. (2021). Perception and Readiness of Students' Towards Online Learning in Nigeria During Covid-19 Pandemic. Library Philosophy and Practice, 5051. https://digitalcommons.unl.edu/libphilprac/5051

Orton-Johnson, K. (2009). "I've stuck to the path I'm afraid": Exploring student non-use of blended learning. British Journal of Educational Technology, 40(5), 837-847. https://doi.org/10.1111/j.1467-8535.2008.00860.x.

Paechter, M., \& Maier, B. (2010). Online or face-to-face? Students' experiences and preferences in e-learning. Internet and Higher Education, 13(4), 292-297.

Pallant, J. (2010). SPSS survival manual - a step by step guide to data analysis using SPSS for windows (version 10). Buckingham Open University Press.

Qunfei, X., Abdullah, N., \& Mustapha, S. M. (2020). The Influencing Factors and Incentive Measures of College Students' Online English Learning Motivation. Journal of Education and Social Sciences, 15(2), 74-81.

Sharma, K., Deo, G., Timalsina, S., Joshi, A., Shrestha, N., \& Neupane, H. C. (2020). Online Learning in the Face of COVID-19 Pandemic: Assessment of Students' Satisfaction at Chitwan Medical College, Nepal. Kathmandu Univ Med J. 2020, COVID-19 Special Issue, 70(2), 40-7.

Smart, K. L., \& Cappel, J. J. (2006). Students' perceptions of online learning: A comparative study. Journal of Information Technology Education, 5, 201-219.

Warner, D., Christie, G., \& Choy, S. (1998). Readiness of VET clients for flexible delivery including on-line learning. Brisbane: Australian National Training Authority.

Widodo, S. F. A., Wibowom Y. E.m and Wagiranm W. (2020). Online learning readiness during the Covid-19 pandemic. Journal of Physics: Conference Series, 1700. doi:10.1088/1742-6596/1700/1/012033 